\title{
Heritability of Plant Height and Head Diameter in Sunflower (Helianthus annuus L.)
}

\author{
Milan Jocković • Siniša Jocić • Radovan Marinković • \\ Slaven Prodanović • Petar Čanak • Mihajlo Ćirić • Petar Mitrović
}

\author{
received: 25 May 2013, revised: 19 June 2013, accepted: 29 July 2013 \\ published online: 5 November 2013 \\ (c) 2013 IFVC \\ doi: $10.5937 /$ ratpov $50-3923$
}

\begin{abstract}
Summary: Purpose of this study was to estimate heritability, in broad and narrow sense, for sunflower plant height and head diameter in order to evaluate success of selection of these traits. Fifteen sunflower populations were evaluated. Heritability values, in broad and narrow sense, were estimated in order to find out the proportion of genetic and additive factors in phenotypic expression of these traits. Study showed that the broad sense heritability for plant height ranged from $6.73 \%$ to $72.53 \%$, while in the narrow sense it ranged from $4.76 \%$ to $95.44 \%$. The broad and narrow sense heritability, for head diameter, varied from $0.15 \%$ to $52.58 \%$ and from $26.27 \%$ to $94.61 \%$. Differences in heritability estimates are attributable to different genetic background of studied populations.
\end{abstract}

Key words: broad sense heritability, genetic factors, head diameter, narrow sense heritability, phenotypic expression, plant height, populations, sunflower seeds.

\section{Introduction}

Plant height and head diameter always had important role in breeding strategy of sunflower (Helianthus annuus L.). In earlier periods of cultivation the Russian peasants took seeds for sowing from plants that had high and strong stem and a large head. Previous studies have found that plant height and head diameter are important traits affecting the yield in sunflower (Miller \& Fick 1997, Gvozdenović et al. 2005, Jocković et al. 2012).

Cultivation of sunflower in regions with various climatic and soil conditions resulted in the creation of varieties and hybrids with different plant heights. Plant height is considered a quantitatively inherited character (Putt 1966, Marinković et al. 1982) with optimum height between 150 and 170 cm (Marinković et al. 2011). Earlier study showed

M. Jocković $\bullet$ S. Jocić • R. Marinković • P. Čanak • M. Ćirić • P. Mitrović

Institute of Field and Vegetable Crops, 30 Maksima Gorkog, 21000

Novi Sad, Serbia

e-mail: milan.jockovic@nsseme.com

S. Prodanović

University of Belgrade, Faculty of Agriculture in Zemun, 6 Nemanjina, 11080 Beolgrade-Zemun that plant height had the highest genotypic effect on seed yield (Jocković et al. 2012). Head diameter is of great importance in sunflower breeding because it has direct influence on seed yield via number of flowers and seeds. Previous studies showed that head diameter had high positive direct influence on sunflower seed yield (Farhatullah et al. 2006, Machikowa \& Saetang 2008, Yasin \& Singh 2010).

Success in the breeding process largely depends on heritability, a proportion of genetic variance in total phenotypic variance. Heritability provides characterization of genetic structure in populations, varieties and F2 generations (Marinković et al. 2003). The higher genetic proportion, the higher is heritability and selection for certain trait can be performed in earlier generations (Mijić et al. 2009), and simpler are the selection procedures (Gill et al. 1998). Heritability is divided into two forms, the broad and the narrow sense, according to Lush (1945). The broad sense heritability

\footnotetext{
Acknowledgements:

This study is part of the research project no. TR-31025 "Development of new varieties and production technology improvement of oil crops for different purposes" sponsored by the Ministry of Education, Science and Technological Development of Republic of Serbia
} 
represents the ratio between genetic and total phenotypic variance, while in the narrow sense it represents the ratio between additive variance and general phenotypic variance. Both forms are not equally important for breeders. The broad sense heritability is of less importance in practice than in theory and cannot be used efficiently to estimate breeding value. It represents the variance of different genotypes (Vidović 1993). The narrow sense heritability is of greater importance because it indicates how much parents phenotypes is a safe indication of their genotypes. Differences in heritability can be attributed to different genetic background for specific trait, therefore knowledge about heritability values in materials of interest is of great interest. Low values indicate that phenotypic expression of a trait is mostly due to non-genetic causes and selection should be performed in later generations, while higher values indicate that phenotypic expression is mostly due to genetic factors and selection for studied trait can be performed in earlier generations.

The aim of this study was to estimate heritability values for plant height and head diameter in sunflower in order to evaluate success of selection of these traits.

\section{Materials and Methods}

Initial material for this study included six sunflower varieties provided by the Institute of Field and Vegetable Crops, Novi Sad, Serbia. Material was crossed during 2010 according to scheme of incomplete diallel and during 2011 were produced $15 \mathrm{~F} 2$ and $30 \mathrm{BC}$ generations. In 2012 parents, F1, $\mathrm{F} 2$ and $\mathrm{BC}$ generations were sown in a randomized block design in three replicates at the experimental field Rimski Šančevi of the Institute of Field and Vegetable Crops in Novi Sad. Plants were sown in $3.6 \mathrm{~m}$ long rows with $70 \times 30 \mathrm{~cm}$ plant spacing. Basic plot size for parents, $\mathrm{F} 1$ and $\mathrm{BC}$ generations included four rows while for $\mathrm{F} 2$ generation 8 rows. Plant height and head diameter were measured in the stage of physiological maturity. The broad sense heritability was estimated using the formula according to Mahmud and Kramer (1951):

$$
\mathrm{h}_{\mathrm{b}}^{2} \frac{\delta^{2} \mathrm{~F}_{2}-\sqrt{ } \delta^{2} \mathrm{P}_{1} \mathrm{x} \delta^{2} \mathrm{P}_{2}}{\delta^{2} \mathrm{~F}_{2}}=\mathrm{x} 100
$$

and the narrow sense according to Warner (1952):

$$
\mathrm{h}_{\mathrm{a}}^{2} \frac{2 \delta^{2} \mathrm{~F}_{2}-\left(\delta^{2} \mathrm{~B}_{1} \mathrm{x} \delta^{2} \mathrm{~B}_{2}\right)}{\delta^{2} \mathrm{~F}_{2}}=\mathrm{x} 100
$$

\section{Results and Discussion}

Heritability estimates, in broad and narrow sense, for plant height are shown on Graph. 1. The heritability values are categorized according to Robinson et al. (1949): 0-30\% low, 31-60\% moderate and over $60 \%$ high. Heritability values for plant height in the present study were low to high. The results showed that the broad sense heritability for plant height varied from $6.73 \%$ to $72.53 \%$, while in the narrow sense it ranged from $4.76 \%$ to $95.44 \%$ (Table 1). Low values of the broad sense heritability in progeny of crosses $\mathrm{S} 1 \mathrm{xS} 2$, S1xS4, S1xS6 and S5xS6 indicate that phenotypic expression is not due to genetic factors and

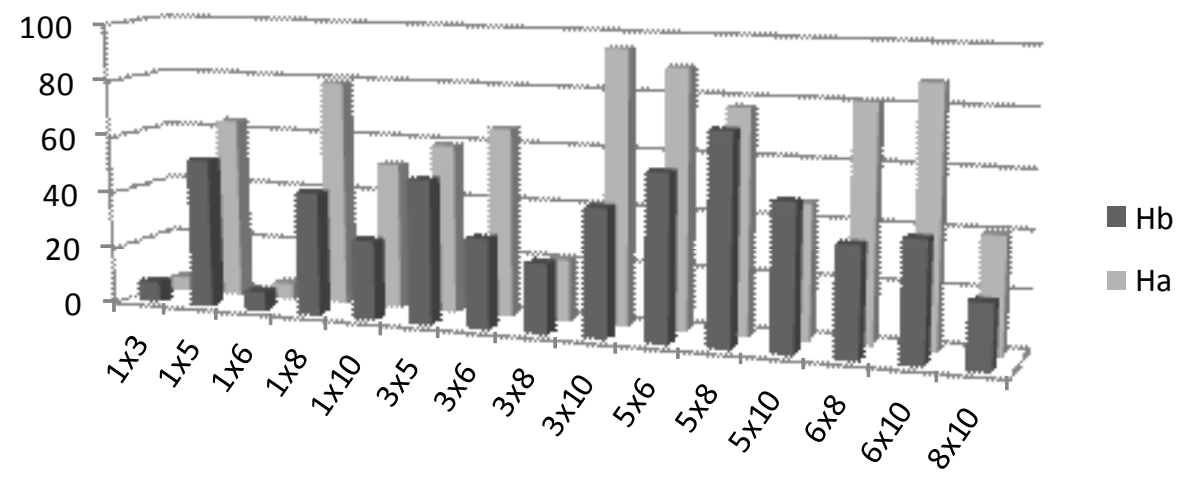

Graph. 1. Heritability estimates, in broad (h2b) and narrow (h2a) sense, for plant height in 15 sunflower populations Grafik 1: Procena heritabilnosti, u širem (h2b) i užem (h2a) smislu, za visinu biljke kod 15 populacija suncokreta 
selection should be performed in later generation. Moderate to high values of heritability in other populations in this study suggests that selection for this trait can be effective in earlier generations because of high proportion of the genetic basis in phenotypic expression. The highest estimates of the narrow sense heritability in populations $\mathrm{S} 2 \mathrm{xS} 6$, S3xS4 and S4xS6 indicate a successful selection for this trait due to high portion of additive effects. Marinković et al. (2012), using different methods for evaluation, reported that heritability values for plant height were moderate to high, in both sense.
Other studies reported similar results, where in earlier study Sridhar et al. (2006) determined very high value $(99.43 \%$ ) for the broad sense heritability, while Mijić et al. (2009) reported that the broad sense heritability estimate was moderate.

Magnitude of heritability estimates, in broad and narrow sense, for head diameter is shown on Graph. 2. Low to moderate estimates in the broad sense heritability are determined for head diameter, while in the narrow sense estimates were low to high. The lowest $(0.15 \%)$ broad sense heritability was estimated for population

Table 1 . Average values, variances and heritability estimates in 15 sunflower populations

Tabela 1. Prosečne vrednosti, varijanse i procene heritabilnosti kod 15 populacija suncokreta

\begin{tabular}{|c|c|c|c|c|c|c|c|c|}
\hline \multirow{3}{*}{ 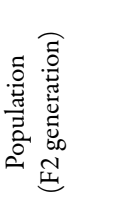 } & \multicolumn{4}{|c|}{ Plant height } & \multicolumn{4}{|c|}{ Head diameter } \\
\hline & \multirow[t]{2}{*}{$\mathrm{X}(\mathrm{cm})$} & \multirow[t]{2}{*}{$\delta^{2}$} & \multicolumn{2}{|c|}{$\mathrm{h}^{2}(\%)$} & \multirow[t]{2}{*}{$\mathrm{X}(\mathrm{cm})$} & \multirow[t]{2}{*}{$\delta^{2}$} & \multicolumn{2}{|c|}{$h^{2}(\%)$} \\
\hline & & & $\mathrm{h}_{\mathrm{b}}^{2}$ & $\mathrm{~h}_{\mathrm{a}}^{2}$ & & & $\mathrm{~h}_{\mathrm{b}}^{2}$ & $\mathrm{~h}_{\mathrm{a}}^{2}$ \\
\hline$S 1 x S 2$ & 163.77 & 210.47 & 7.23 & 4.76 & 19.48 & 19.28 & 36.55 & 71.73 \\
\hline S1xS3 & 164.83 & 270.90 & 52.65 & 63.96 & 19.79 & 17.80 & 16.54 & 48.2 \\
\hline S1xS4 & 186.85 & 136.04 & 6.73 & 5.47 & 19.00 & 13.28 & 0.15 & 38.62 \\
\hline S1xS5 & 184.73 & 206.07 & 43.45 & 79.51 & 20.97 & 19.90 & 16.95 & 90.95 \\
\hline S1xS6 & 149.71 & 176.39 & 28.00 & 51.48 & 18.74 & 15.09 & 4.49 & 32.14 \\
\hline $\mathrm{S} 2 \mathrm{xS} 3$ & 169.18 & 190.04 & 50.58 & 59.26 & 19.20 & 17.57 & 22.52 & 66.88 \\
\hline $\mathrm{S} 2 \mathrm{xS} 4$ & 171.46 & 202.10 & 31.74 & 66.15 & 20.78 & 22.53 & 46.07 & 94.23 \\
\hline $\mathrm{S} 2 \mathrm{xS} 5$ & 159.90 & 167.41 & 24.32 & 21.55 & 19.79 & 21.11 & 34.95 & 87.83 \\
\hline $\mathrm{S} 2 \mathrm{xS} 6$ & 142.24 & 250.52 & 44.88 & 95.44 & 21.08 & 27.85 & 52.58 & 91.10 \\
\hline S3xS4 & 157.31 & 215.17 & 57.88 & 89.79 & 22.49 & 25.40 & 41.91 & 94.61 \\
\hline S3xS5 & 133.67 & 302.98 & 72.53 & 77.45 & 12.39 & 29.86 & 44.16 & 63.40 \\
\hline S3xS6 & 148.68 & 184.55 & 50.85 & 46.65 & 20.81 & 18.04 & 11.10 & 43.68 \\
\hline S4xS5 & 168.09 & 197.48 & 38.10 & 81.12 & 21.01 & 20.31 & 26.72 & 57.56 \\
\hline S4xS6 & 173.97 & 227.57 & 41.45 & 88.22 & 19.52 & 16.10 & 11.09 & 26.27 \\
\hline S5xS6 & 152.95 & 157.53 & 22.32 & 40.22 & 21.49 & 23.78 & 31.97 & 48.19 \\
\hline
\end{tabular}

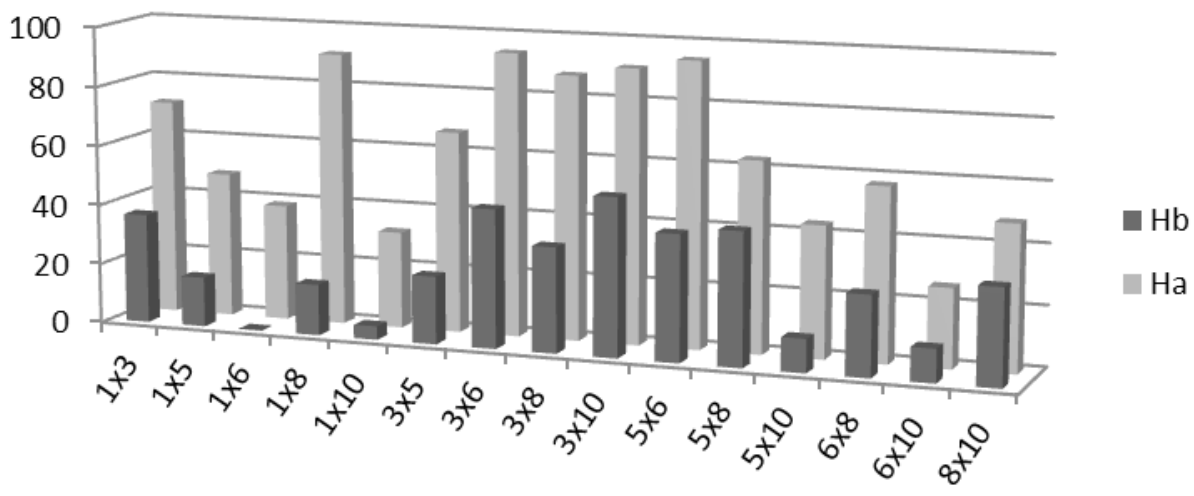

Graph. 2. Heritability estimates, in broad (h2b) and narrow (h2a) sense, for head diameter in 15 sunflower populations Grafik 2. Procene heritabilnosti, u širem (h2b) i užem (h2a) smislu, za prečnik glave kod 15 populacija suncokreta 
S1xS4 and the highest (52.58\%) for population S2xS6 (Table). Our results are similar to those in previous studies where Khan et al. (2001) reported moderate estimate $(54.27 \%)$ and Safavi et al. (2011) determined low estimate of the broad sense heritability for head diameter. Contrary to our and the results of aforementioned authors, Sridhar et al. (2006) reported high estimate (92.05\%) of the broad sense heritability for head diameter. The narrow sense heritability estimates ranged from $26.27 \%(\mathrm{~S} 4 \mathrm{xS6}$ ) to $94.61 \%(\mathrm{~S} 3 \mathrm{xS} 4)$. Although the broad sense heritability estimates were not high, populations S3xS4, S2xS4, S2xS6, S1xS5 and $\mathrm{S} 2 \mathrm{xS} 5$ expressed high estimates of the narrow sense heritability, which is of greater importance, indicating successful selection because phenotypic expression is mostly due to additive effects and not due to dominance and epistasis. Our results are in accordance with results of Marinković et al. (2012) who also reported low to high narrow sense heritability estimates for head diameter.

\section{Conclusions}

For successful breeding process it is necessary to obtain information on all parameters that can influence the direction of selection. Heritability is valuable parameter in breeding process. Estimates of heritability, in broad and narrow sense, provides information on proportion of genetic and additive effects in phenotypic variance and thus evaluate the success of selection on studied trait. For a more accurate estimate of heritability it is necessary to observe studied parameters in few years (or different environments) because of their quantitative nature. Results from this study showed that heritability estimates, in both sense, were very different which is explained due to differences in genetic background in studied populations. Considering plant height, in populations $S 1 \mathrm{xS} 2$, S1xS4, S1xS6 and S5xS6 selection for this trait should be performed in later generations due to lower heritability values and higher influence of non-genetic factors. Populations S2xS6, S3xS4 and $\mathrm{S} 4 \mathrm{xS} 6$ expressed high values of the narrow sense heritability suggesting success in selection for this trait. Head diameter expressed low to mid estimates in the broad sense while low to high estimates in the narrow sense heritability. The most successful selection for head diameter can be expected from populations $\mathrm{S} 3 \mathrm{xS} 4, \mathrm{~S} 2 \mathrm{xS} 4, \mathrm{~S} 2 \mathrm{xS6}$, S1xS5 and S2xS5 because of high additive gene effect in genetic basis of studied trait. 


\section{References}

Farhatullah, E. A., Farooq, I. H., \& Khalil (2006). Path analysis of the coefficients of sunflower (Helianthus annus L.). Int. J. Agri. Biol., 8(5), 621-625.

Gill, H. S., Khurana, S. R., Yadava, T. P., \& Sheoran, R. K. (1998). Expression of heterosis for different characters in sunflower over environments. Haryana Agric. Uni. J. Res., 28(2-3), 95100.

Gvozdenović, S., Joksimović, J., \& Škorić, D. (2005). Gene effect and combining abilities for plant height and head diameter in sunflower. Genetika, 37(1), 57-64.

Jocković, M., Marinković, R., Marjanović-Jeromela, A., Radić, V., Čanak, P., \& Hladni, N. (2012). Association between Seed Yield and Some Morphological Characteristics in Sunflower. Ratar. Povrt. 49(1), 53-57.

Khan, A., Malik, N. J., Khan, M. I., \& Riaz, S. (2001). Growth performance, heritability and inter relationship in some quantitative traits in sunflower. Online Journal of Biological Sciences, 1(10), 895-897.

Lush, J. L. (1945). Animal breeding plans. Iowa State University Press. Ames, IA.

Machikowa, T., \& Saetang, C. (2008). Correlation and path coefficient analysis on seed yield in sunflower. Suranaree J. Sci. Technol., 15(3), 243-248.

Mahmud, I., \& Kramer, H. H. (1951). Segregation for yield, height and maturity following a soybean cross. Agronomy Journal, 43, 605-609.

Marinković, R., Dozet, B., \& Vasić, D. (2003). Oplemenjivanje suncokreta (monografija). Školska knjiga, Novi Sad.

Marinković, R., Jocković, M., Jocić, S., \& Ćirić, M. (2011). Variability of Plant Height and Head Diameter in New Hybrid Combinations of Sunflower. Ratar. Povrt. 48(1), 239-244.

Marinković, R., Jocković, M., Marjanović-Jeromela, A., Atlagić, J., Miladinović, D., \& Radić, V. (2012). Application of different methods in the determination of heritability of some quantitative traits in the sunflower (Helianthus annuus L.) sinthetic NS-S-1. Proceedings of the 18th Sunflower International Conference, February 27 - March 1st, Mar del Plata, Argentina, 669-673.

Marinkovic, R. (1982). Inheritance of plant height and leaf number in diallel crossings of sunflower inbreds. pp. 232-233. In: Proc. 10th Int. Sunflower Conf. Surfers Paradise, Australia, 14-18 March 1982. Int. Sunflower Assoc. Toowoomba, Australia.

Mijić, A., Liović, I., Zdunić, Z., Marić, S., Marjanović-Jeromela, A., \& Jankulovska, M. (2009). Quantitative analysis of oil yield and its components in sunflower (Helianthus annuus L.). Romanian Agricultural Research, 26, 41-46.

Miller, J. F., \& Fick, G. N. (1997). Sunflower Genetics. In: A.A. Schneiter (ed.), Sunflower Technology and Production. Agron. Monogr. 35. Madison, WI, USA, pp. 441-495.

Putt, E. D. (1966). Heterosis, combining ability and predicted synthetics from a diallel cross in sunflower. Can. J. Plant Sci. 46, 59-67.

Robinson, H. F., Comstock, R. E., \& Harvey, P. H. (1949). Estimates of heritability and degree of dominance in corn. Agron. J. 41, 353-359.

Safavi, S. M., Safavi, A. S., \& Safavi, S. A. (2011). Heritability and genetic gain of some morphological traits in sunflower (Helianthus annuus L.) under water stress conditions. American Journal of Scientific Research, 19, 27-31.

Sridhar, V., Gouri, Shankar, V., \& Dangi, S. (2006). Variability parameters for yield and its components in sunflower (Helianthus annuus L.). Agric. Sci. Digest, 26(4), 288-290.

Vidović, V. (1993). Principi i metodi oplemenjivanja životinja. Feljton, Novi Sad.

Warner, N. J. (1952). A method for estimating heritability. Agronomy Journal, 44, 427-430.

Yasin, A. B., Singh, S. (2010): Correlation and path coefficient analysis in sunflower. J. Plant. Breed. Crop Sci. 2(5), 129-133.

\title{
Heritabilnost visine biljke i prečnika glave kod suncokreta
}

\author{
Milan Jocković • Siniša Jocić • Radovan Marinković • \\ Slaven Prodanović • Petar Čanak • Mihajlo Ćirić • Petar Mitrović
}

Sažetak: Svrha ovog rada je bila da se proceni heritabilnost, u širem i užem smislu, za visinu biljke i prečnik glave kod suncokreta sa ciljem da se oceni uspeh selekcije ovih svojstava. Ispitivano je petnaest populacija suncokreta. Vrednosti heritabilnosti, u širem i užem smislu, su procenjene sa ciljem da se sazna udeo genetičkih i aditivnih faktora u fenotipskoj ekspresiji ovih svojstava. Studija je pokazala da se heritabilnost visine biljke, u širem smislu kretala od 6,73\% do $72,53 \%$, dok se u užem smislu kretala od 4,76\% do 95,44\%. Heritabilnost prečnika glave, u širem i užem smislu, varirala je od $0,15 \%$ do $52,58 \%$ i od $26,27 \%$ do $94,61 \%$. Razlike u procenama heritabilnosti se mogu pripisati različitoj genetičkoj pozadini ispitivanih populacija.

Ključne reči: fenotipska ekspresija, genetski faktori, heritabilnost u širem smislu, heritabilnost u užem smislu, populacije, prečnik glave, suncokret, visina biljke 